\title{
Photoactive Hybrid Catalysts Based on Natural and Synthetic Polymers: A Comparative Overview
}

\author{
Juan Carlos Colmenares * and Ewelina Kuna \\ Institute of Physical Chemistry, Polish Academy of Sciences, Kasprzaka 44/52, 01-224 Warsaw, Poland; \\ ekuna@ichf.edu.pl \\ * Correspondence: jcarloscolmenares@ichf.edu.pl; Tel.: +48-22-343-3215 \\ Academic Editor: Pierre Pichat \\ Received: 18 March 2017; Accepted: 7 May 2017; Published: 12 May 2017
}

\begin{abstract}
In the present review, we would like to draw the reader's attention to the polymer-based hybrid materials used in photocatalytic processes for efficient degradation of organic pollutants in water. These inorganic-organic materials exhibit unique physicochemical properties due to the synergistic effect originating from the combination of individual elements, i.e., photosensitive metal oxides and polymeric supports. The possibility of merging the structural elements of hybrid materials allows for improving photocatalytic performance through (1) an increase in the light-harvesting ability; (2) a reduction in charge carrier recombination; and (3) prolongation of the photoelectron lifetime. Additionally, the great majority of polymer materials exhibit a high level of resistance against ultraviolet irradiation and improved corrosion resistance. Taking into account that the chemical and environmental stability of the hybrid catalyst depends, to a great extent, on the functional support, we highlight benefits and drawbacks of natural and synthetic polymer-based photocatalytic materials and pay special attention to the fact that the accessibility of synthetic polymeric materials derived from petroleum may be impeded due to decreasing amounts of crude oil. Thus, it is necessary to look for cheap and easily available raw materials like natural polymers that come from, for instance, lignocellulosic wastes or crustacean residues to meet the demand of the "plastic" market.
\end{abstract}

Keywords: photoactive hybrid materials; photocatalyst; biopolymers; synthetic polymers; water/air detoxification; metal oxides

\section{Introduction}

In recent years, the interest in photocatalysis as a green and eco-friendly method for pollution remediation [1,2], energy conversion [3,4] or chemical synthesis [5] has been increasing. However, the proficient application of photocatalysis is restricted to the fabrication of advanced nanostructured materials consisting of various types of semiconductors [6-11]. Current research in this field mainly concentrates on the development of hybrid materials containing photoactive metal oxides [9-13], quantum dots, or perovskites $[14,15]$ to enhance the efficiency of photocatalytic systems [16]. In order to understand the main restrictions of photocatalytic performance, we have to know the main photochemical and photophysical mechanisms leading that process (Figure 1) [16-20]. It is worth mentioning that correlation between semiconductors and light plays a crucial role in the case of photocatalysis $[12,16]$. The absorption of photons with a specific energy allows for excitation of electrons from the valence band to the conduction band, producing hole-electron pairs responsible for redox processes. However, oxidation and reduction processes can be inhibited due to charges and radical recombination or back electron transfer processes [21,22]. Consequently, the employed photonic power is much higher than desirable rate of the desired chemical transformation, which is the main limitation of photocatalytic performance [23]. 
Significant features which can extensively improve photocatalytic efficiency and light absorption capability, are strongly correlated to size and structure of photocatalytic materials, their specific surface area, or crystalline phase $[7,24]$. Taking into consideration the fact that the required physicochemical characteristics are a consequence of various features of the main components and interaction between them $[25,26]$, the enhancement of photocatalytic performances could be obtained through an organic-inorganic hybrid complex made of a semiconductor and suitable support [25]. Multiple material combinations provide synergistic effects that are able to create and improve properties of nanomaterials [27-29] which are beneficial for enhancing the efficiency of photocatalytic reactions. The synergistic effect originating from the combination of individual elements is clearly evident in the case of polymer-based hybrid photocatalysts. A great majority of polymer materials exhibits a high level of resistance against ultraviolet irradiation and improved corrosion resistance as well as environmental stability $[30,31]$. Compared with semiconductor oxides, the great majority of polymeric supports are chemically inert, mechanically stable, inexpensive and easily available. Additionally, the hydrophobic nature of polymer gives an advantage to congregate the organic pollutants on the surface and raise the efficiency of adsorption and subsequent degradation reaction rates [32]. Therefore, in recent years polymer-based hybrid materials have been emerging as promising device in the photocatalytic field.

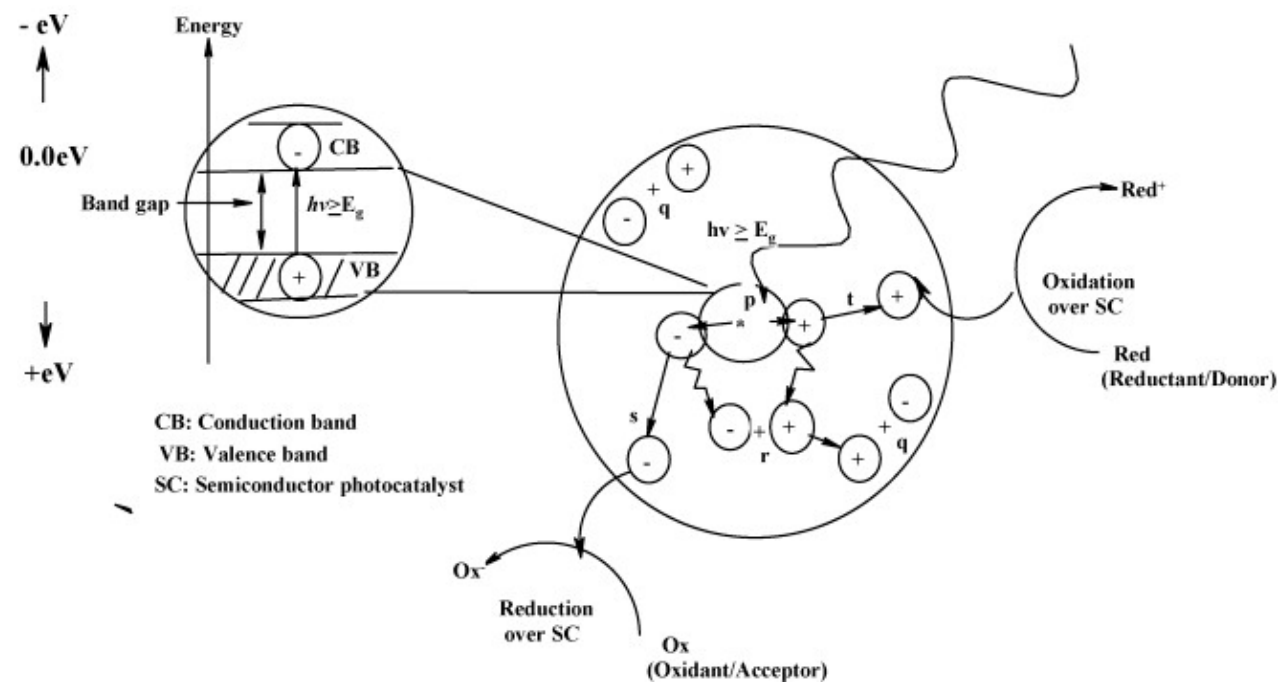

Figure 1. Photochemical and photophysical processes over photon-activated semiconductors, where: $(p)$ is photogeneration of electron/hole pair, $(q)$ is surface recombination, $(r)$ is recombination in the bulk, (s) is diffusion of acceptor and reduction on the surface of semiconductor and $(t)$ is oxidation is oxidation of donor on the surface of semiconductor particle. Reprinted from [31] with permission from Elsevier.

Nowadays, plastic production is based mainly on feedstock derived from petroleum refineries. A wide range of synthetic or semisynthetic polymerization products are obtained from oil and gas, which undergo chemical processing [33]. As inputs for plastic manufacturing, refinery olefins (mainly propylene and less quantities of ethylene or butylenes) are produced from alkane transformations [34]. Unfortunately, there are difficulties with the discovery of new oil deposits, and some sedimentary basins that contain crude oil have already been explored. The oilfields which still have not been explored are located in inaccessible regions of the world [35]. Taking into consideration the fact that the plastic production is based mainly on feedstock derived from oil refinery, it is necessary to look for cheap and easily available raw materials like highly abundant biopolymers in nature. In this state-of-the-art review, we focus on synthetic and natural polymers, and highlight the main benefits and limitations coming from polymer materials which could be used as support for the fabrication of photocatalytic hybrid materials. 


\section{Synthetic and Natural Polymers}

According to IUPAC (International Union of Pure and Applied Chemistry) nomenclature, the word "polymer" refers to substances composed of macromolecules with high relative molecular mass. However, this term could be also be applied to polymer substances, polymer blends or polymer molecules [36]. Additionally, polymers include a wide class of materials which can be grouped according to source, functionalities, structure, thermal behavior, polymerization mechanism or preparation techniques (Figure 2) [37,38]. In this mini-review, we mainly focus on synthetic and natural polymers, which can find applications in photocatalysis, taking into consideration factors related to the photocatalytic properties, including stability, biodegradability, and biocompatibility with inorganic materials as well as following recent progress on the synthesis of hybrid materials.

\section{Classification of polymers}

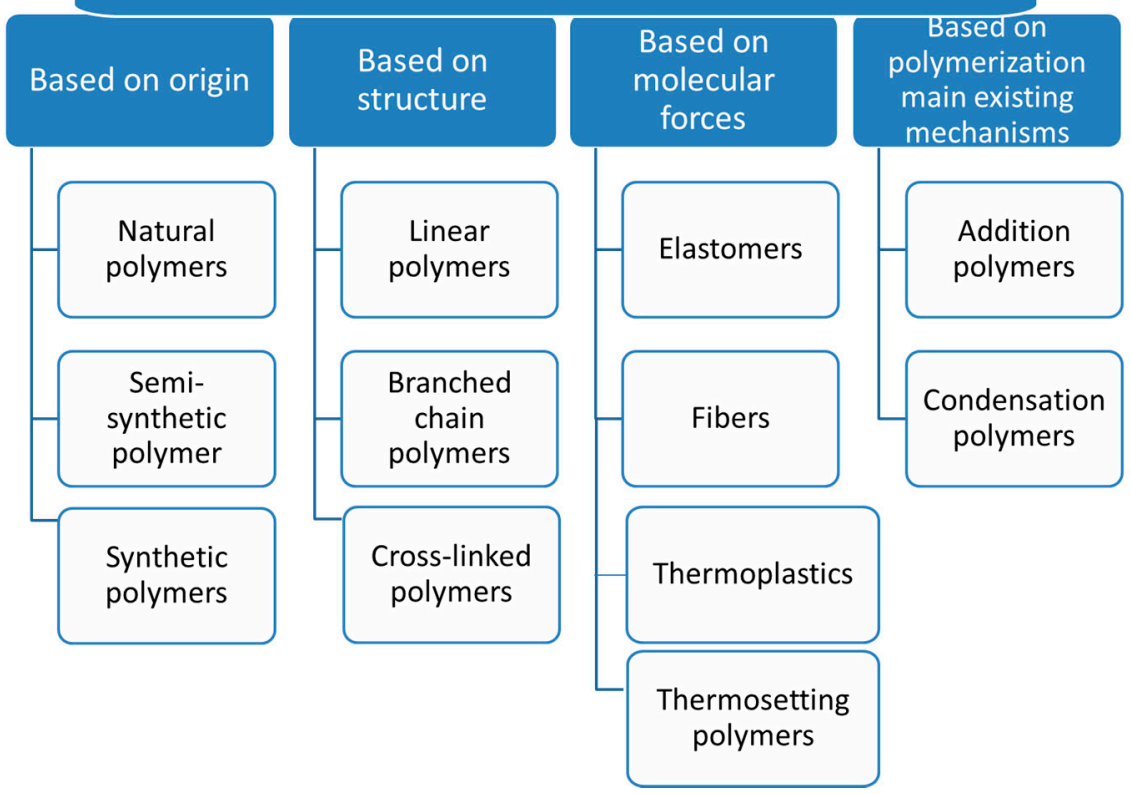

Figure 2. Classification of polymers according to [37].

Synthetic and semisynthetic polymers originating from crude oil have had a huge impact on modern science and technology due to their physicochemical properties. In many cases, chemical, physical and biological resistance play crucial roles in the selection of a desirable polymer for determined function. However, with respect to most synthetic materials, the affected time-resistant properties of polymeric wastes can lead to the release of toxic degradation products during decomposition which is not acceptable from an eco-friendly point of view [38]. Owing to concerns about the natural environment and shortages of non-renewable sources, the interest in polymers derived from natural sources like starch, lignocellulose or proteins is still increasing [34]. Biodegradable polymers that can be obtained from renewable resources (Figure 3) have emerged as environmentally friendly substitutes for non-biodegradable materials. It is worth mentioning that some of them exhibit similar or superior mechanical properties to petroleum-based polymers [39]. However, in many cases they possess inferior physical feature in terms of stability and strength and lots of them require high-cost production [33]. Additionally, in comparison with synthetic polymers, several natural polymers cannot be processed into a wide range of shapes, due to the fact that the high processing temperature destroys their structure [40]. Consequently, the design of new eco-friendly and highly efficient and stable photocatalytic biopolymer hybrid materials is challenging. 


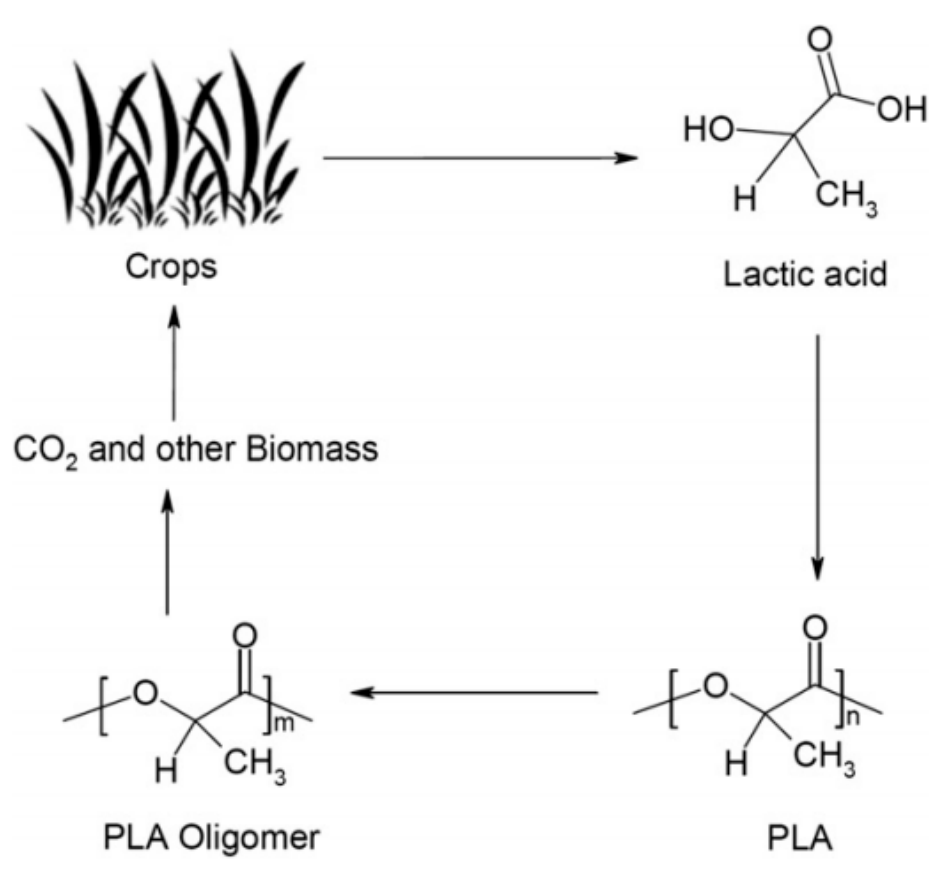

Figure 3. Life cycle of polylactide (PLA), an example of biodegradable synthetic polymers. Reprinted from [41] with permission from Elsevier.

\subsection{Photocatalytic Hybrid Materials Based on Synthetic Polymers}

Various types of synthetic polymer shave been reported as photocatalytic supports in the literature, namely: polyethylene (PE) [42], polypropylene (PP) [43], polystyrene (PS) [44], polyethylene terephthalate (PET) [45], polyvinyl chloride (PVC) [46], polyvinyl alcohol (PVA) [47], polycarbonate (PC) [48] and so on. To our best knowledge, the first attempt to produce polymer hybrid materials was made in 1995 by Tennakone [49]. Titanium oxide with polyethylene films as support was used for the photocatalytic decomposition of phenol with a high degradation ratio $(50 \%$ after $2.5 \mathrm{~h}$ of illumination). Further, experimental studies on polypropylene non-woven with zinc oxide nanorods indicate that this kind of photocatalytic materials exhibited not only excellent catalytic activity but also high stability $[50,51]$. Hence, these hybrid materials can be successfully used for water treatment processes by acting as photocatalysts and filters at the same time [52]. Additionally, the synergetic effect of the combination of metal oxide and polymers allows for protection of the polypropylene fiber against surface cracks and limits the well-known photocorrosion process of zinc oxide [52,53]. Similar photoactive hybrid materials based on polybutylene terephthalate (PBT) polymer fiber mats were used for photocatalytic dye degradation. These studies confirmed that the catalyst supported on the polymer mat could be reused without a particular recovery step [54]. They also pointed out the fact that the combination of proper fabrication methods allows for better photocatalytic performance (Table 1 , Entry 1) [55]. Another example of synthetic polymer hybrid materials, which have applications in water treatment processes, are polyethersulfone or polyvinylidene fluoride membranes with various types of metal oxides (e.g., titanium, zinc or chromium) displaying good antifouling performance, including photo-catalysis, self-cleaning, and filterability properties [55,56]. Our special attention gives merit to hybrid materials based on conjugated organic polymers (COPs) like polyaniline (PANI) [57] (Table 1, Entry 2), poly(pyrrole) (PPy) [58], polythiophene (PT) [59], polyacetylene (PA) [60], poly(methyl methacrylate) (PMMA) [61], polythiopene (PT) [62], polyparaphenylene (PPP) [63], polyparaphenylenevenylene (PPV), poly(3,4-ethylenedioxythiophene) (PEDOT) [63] or poly(O-phenylenediamine) (POPD)) [64]. The conjugated organic polymers are mostly p-type semiconductors, due to their electrical and optical properties. Specifically, their high electron mobility or high photon absorption coefficient under visible spectra has attracted increasing interest 
for photocatalytic applications, e.g., degradation of pollutants or hydrogen generation by water splitting [65]. In terms of water treatment processes, another interesting perspective solution offered by polymeric support is the possibility of fabricating a floatable photocatalyst, the concept of which is shown in Figure 4. These kinds of materials are able to maximize illumination utilization and oxygenation processes of the photocatalyst by approaching the air/water interface, which in the end can result in higher rates of radical formation and oxidation efficiencies [66].

Polymeric supports possess different morphologies and can exist in the form of sheets [67], nanospheres [68], or nanoparticles [69]. Of course in all these cases, polymer materials contribute to an increase the photocatalytic activity of inorganic-organic materials. However, contact surface area of the hybrid photocatalyst, which has a significant influence on their activity, is lower for fiber polymeric supports. Selected examples of catalysts based on polymeric fibers with high photocatalytic activity are shown in Table 1.

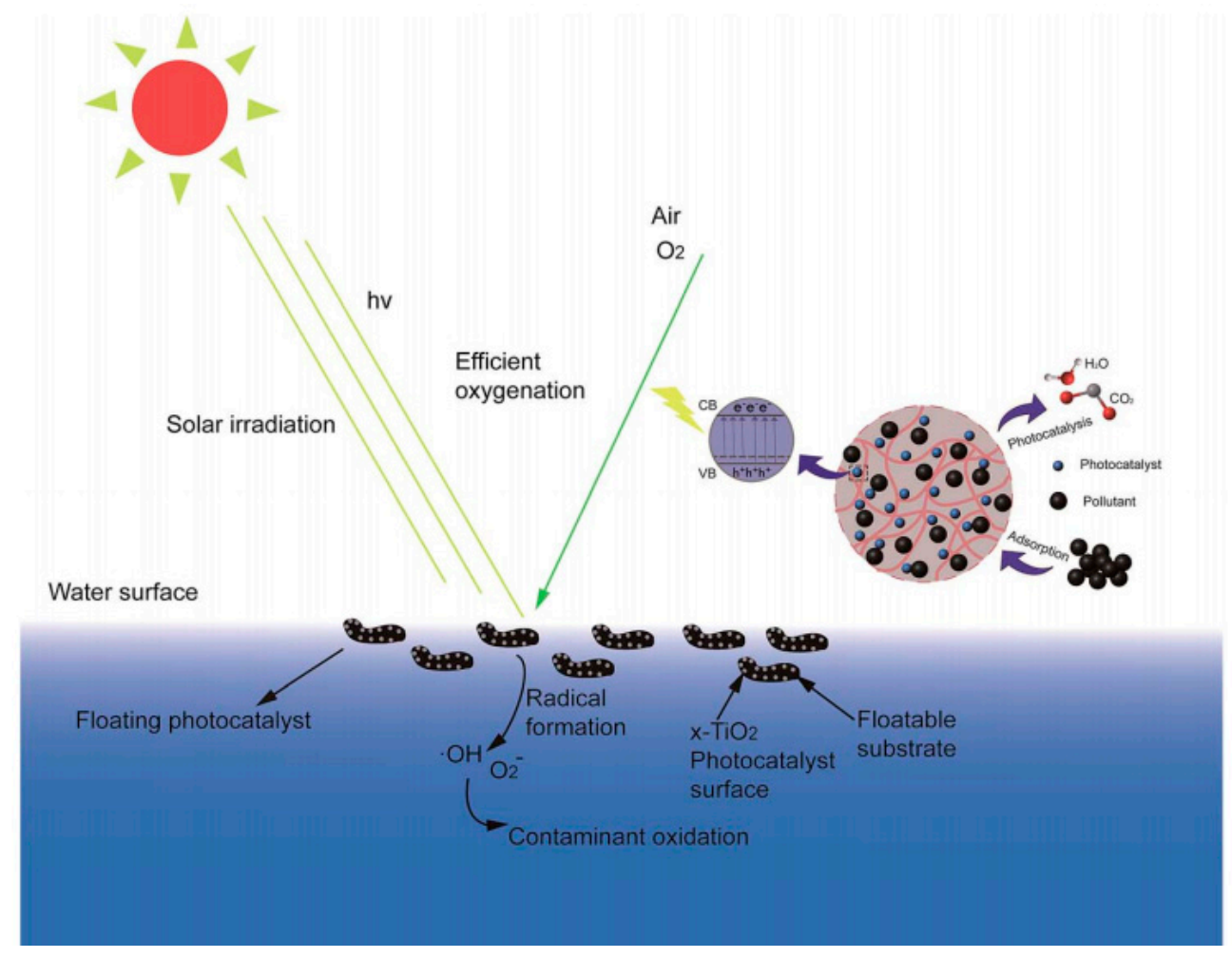

Figure 4. Schematic representation of a floating photocatalyst (CB: conduction band; VB: valence band). Reproduced from reference [70] by permission of the Royal Society of Chemistry.

It is worth mentioning that in the open literature a new class of hybrid materials, represented by coordination polymers (CPs) and composed of metal clusters with organic ligands (Figure 5), can be used in photocatalysis. These crystalline materials possess high dispersion of active sites, tuneable adsorption properties, appropriate pore size and topology [71]. Additionally, the effective solar light absorption properties can be obtained through modifying the composition of the metal cations and organic linkers. The possibility to connect the light-harvesting and catalytic components allows for conversion of solar energy to chemical energy by artificial photosynthesis [72]. Materials based on coordination polymers provide crucial information about synergistic effects derived from multiple elements of hybrid materials and allow for understanding the fundamental principles about light harvesting and energy transfer phenomena, schematically explained in Figure 6. In spite of some examples of CP-based heterogeneous photocatalytic systems [73], until now the CP-based soluble complexes have mainly been used in homogenous catalytic processes which is a serious limitation for broad industrial application due mostly to the problem of photocatalyst filtration after the process. 


\section{Coordination polymers (CPs)}

\begin{tabular}{|c|c|}
\hline $\begin{array}{c}\text { Metal organic } \\
\text { framework (MOF) }\end{array}$ & $\begin{array}{c}\text { Metal organic complex } \\
\text { (MOC) }\end{array}$ \\
\hline $\begin{array}{c}\text { - Tunable Porosity } \\
\text { High dimensional framework } \\
\text { - Structure (2D, 3D) }\end{array}$ & $\begin{array}{c}\text { - Super-molecular interaction } \\
\text { - Low dimensional (OD, 1D) or } \\
\text { mononuclear configuration } \\
\text { interaction }\end{array}$ \\
\hline
\end{tabular}

Figure 5. The coordination polymers which consist of the branch of metal organic framework and metal organic complex. Adapted and modified with permission from [72] Copyright (2012) American Chemical Society.

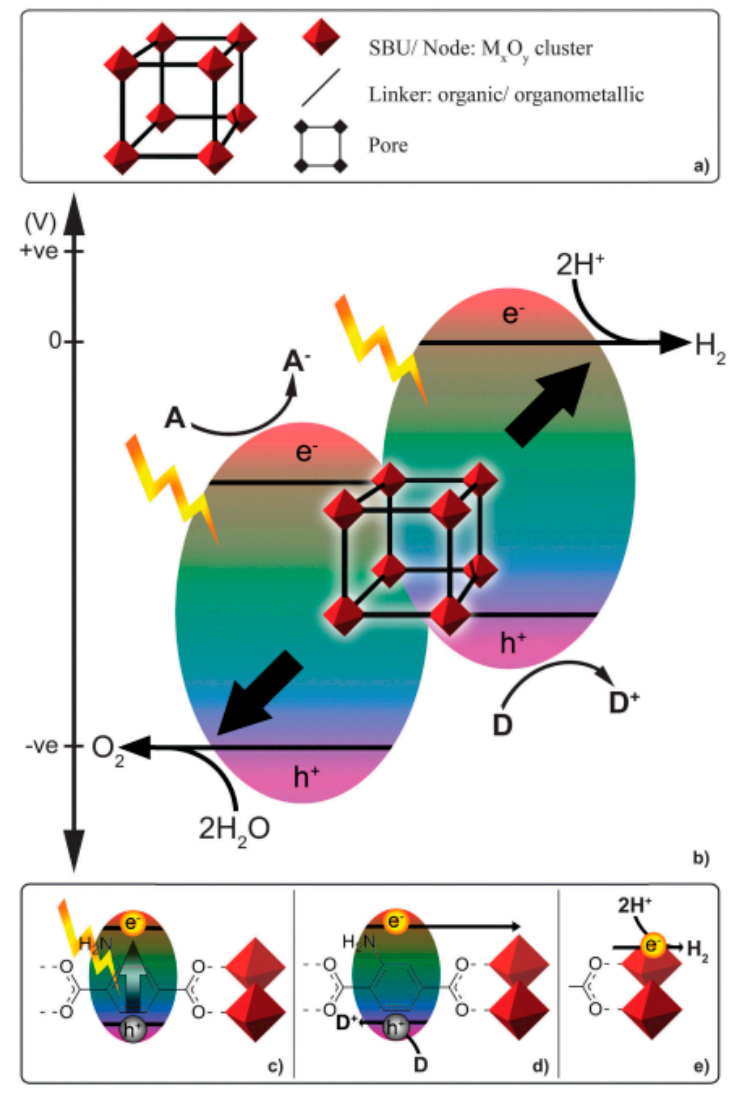

Figure 6. (a) the components of the MOF structure; (b) conceptual schematic for photo-catalyzed water oxidation or reduction using a MOF in the presence of an acceptor or donor; (c) light harvesting accomplished by an organic linker; (d) generation of a charge separated state and quenching of $\mathrm{h}^{+}$by a donor; (e) electron transfer to the metal oxide node and subsequent proton reduction (SBU: secondary building units). Reproduced from reference [73] with permission of The Royal Society of Chemistry. 
Table 1. Selected photocatalytic hybrid materials based on synthetic polymers used for degradation of organic contaminants.

\begin{tabular}{|c|c|c|c|c|c|c|}
\hline Entry & Polymer Hybrid Materials & Target Contaminant & Light Source & Fabrication Method & Photocatalytic Behavior & Ref. \\
\hline 1 & $\begin{array}{l}\mathrm{ZnO} \text { nanorods on polybutylene } \\
\text { terephthalate (PBT) polymer fiber mats }\end{array}$ & Azo organic dye (acid red 40) & $\begin{array}{l}\text { Ultraviolet (UV) radiation in } \\
\text { the range of } 320-390 \mathrm{~nm} \\
\text { providing } 79 \mathrm{~mW} / \mathrm{cm}^{2} \text { of } \\
\text { energy flux. }\end{array}$ & $\begin{array}{l}\text { Thin films formed by low temperature } \\
\text { vapor phase atomic layer deposition } \\
\text { (ALD) and hydrothermal growth of } \mathrm{ZnO} \\
\text { nanorod crystals on a seed layer. }\end{array}$ & $\begin{array}{l}\text { Degradation ratio } \sim 90 \% \text { of the dye within } \\
2 \mathrm{~h} \text {. The combination of ALD and } \\
\text { hydrothermal method allow to obtain the } \\
\text { best performance of the photocatalyst and } \\
\text { may be also used for other crystal growth } \\
\text { systems, such as } \mathrm{TiO}_{2}, \mathrm{Fe}_{2} \mathrm{O}_{3}, \mathrm{SnO}_{2} \text { and } \\
\mathrm{V}_{2} \mathrm{O}_{5} \text {, where high area and ready solution } \\
\text { access are desired. }\end{array}$ & [55] \\
\hline 2 & $\begin{array}{l}\mathrm{ZnO} \text { nanoparticles on wool and } \\
\text { polyacrylonitrile (PANI) fibers }\end{array}$ & $\begin{array}{l}\text { Methylene blue (MB) and eosin } \\
\text { yellowish (EY) dye }\end{array}$ & $\begin{array}{l}\text { High-pressure mercury lamp } \\
\text { covers illumination spectrum } \\
\text { ranging from ultraviolet to } \\
\text { visible }(200-800 \mathrm{~nm}) .\end{array}$ & $\begin{array}{l}\text { Impregnation of polymeric fibers using } \\
\text { sol-gel process at ambient temperature. } \\
\text { ZnO-sol is based on the method } \\
\text { described in the literature with minor } \\
\text { changes in details. }\end{array}$ & $\begin{array}{l}\text { There is } 77 \% \mathrm{MB} \text { dye degradation after } 6 \mathrm{~h} \\
\text { upon } \mathrm{ZnO} / \mathrm{PANI} \text { and } 80 \% \text { upon } \mathrm{ZnO} / \text { wool } \\
\text { fibers, which is 4-fold more in comparison } \\
\text { to bare fibers. Similar results of degradation } \\
\text { were obtained for EY dye, where the } \\
\text { degradation ratios equal } 64 \% \text { and } 50 \% \text {, } \\
\text { respectively. }\end{array}$ & [57] \\
\hline 3 & $\mathrm{CeO}_{2}$-ZnO-polyvinylpyrrolidone (PVP) & Rhodamine B (RhB) & $\begin{array}{l}\text { UV lamp ( } 8 \mathrm{~W}) \text { with emission } \\
\text { wavelengths at } 254 \mathrm{~nm} \text {. }\end{array}$ & $\begin{array}{l}\text { The electrospinning technique was } \\
\text { followed by thermal treatment to obtain } \\
\mathrm{CeO}_{2}-\mathrm{ZnO} \text { nanofibers. The nonwoven } \\
\text { mat was prepared from the precursor } \\
\text { solution of } \\
\mathrm{PVP} / \mathrm{Ce}\left(\mathrm{NO}_{3}\right)_{3} / \mathrm{Zn}\left(\mathrm{CH}_{3} \mathrm{COO}\right)_{2} \text {. }\end{array}$ & $\begin{array}{l}\text { After } 3 \mathrm{~h} \text { of irradiation, only } 17.4 \% \text { and } \\
82.3 \% \text { of Rhodamine } \mathrm{B} \text { was decomposed } \\
\text { catalyzed by pure } \mathrm{CeO}_{2} \text { and } \mathrm{ZnO} \text { fibers, } \\
\text { respectively, whereas almost } 98 \% \text { was } \\
\text { decomposed applying the } \\
\mathrm{CeO}_{2}-\mathrm{ZnO} \text {-composite fibers. }\end{array}$ & [74] \\
\hline 4 & $\mathrm{ZnO}$ nanowires on polyethylene (PP) & Methylene blue (MB) & UV light source $(6 \mathrm{~W})$ & $\begin{array}{l}\mathrm{ZnO} \text { nanowires were grown from seed } \\
\mathrm{ZnO} \text { nanoparticles affixed onto the } \\
\text { commercially available fibers by } \\
\text { hydrothermal method. }\end{array}$ & $\begin{array}{l}\text { After } 2.5 \mathrm{~h} \text { of irradiation, } \mathrm{ZnO} / \text { polyethylene } \\
\text { fibers degraded } 83 \% \text { of the } \mathrm{MB} \text {, whereas the } \\
\text { fibers without } \mathrm{ZnO} \text { degradate only } 32 \% \text {. } \\
24 \% \text { of } \mathrm{MB} \text { was found undergo } \\
\text { self-degradation under the same UV light } \\
\text { without using polyethylene fibers. }\end{array}$ & [75] \\
\hline 5 & $\mathrm{ZnO} / \mathrm{SnO}_{2}$-polyvinylpyrrolidone (PVP) & Rhodamine B & $\begin{array}{l}\text { High-pressure mercury lamp } \\
(50 \mathrm{~W}) \text { with main emission } \\
\text { wavelength at } 313 \mathrm{~nm} .\end{array}$ & $\begin{array}{l}\text { A simple combination method of sol-gel } \\
\text { process and electrospinning technique. } \\
\text { The electrospun composite nanofibers } \\
\text { was obtained by the precursor solution } \\
\text { of } \mathrm{PVP} / \mathrm{ZnCl} / 2 / \mathrm{SnCl}_{2} \text {. }\end{array}$ & $\begin{array}{l}\text { After } 50 \mathrm{~min} \text {, the degradation efficiency of } \\
\mathrm{RhB} \text { was equal to } 75,35 \text {, and } 85 \% \text { for } \mathrm{ZnO} \text {, } \\
\mathrm{SnO}_{2} \text {, and } \mathrm{TiO}_{2} \text { fibers, respectively. } \\
\text { However, the time for complete } \\
\text { decolorization of dye solution over the } \\
\mathrm{ZnO} / \mathrm{SnO}_{2} \text {-nanofibers was } 30 \text { min. }\end{array}$ & [76] \\
\hline 6 & $\begin{array}{l}\text { Reduced graphene oxide/titanium } \\
\text { dioxide filter }\left(\mathrm{RGO} / \mathrm{TiO}_{2} \text { ) and reduced }\right. \\
\text { graphene oxide/zinc oxide filter } \\
\text { (RGO/ZnO) on polypropylene(PP) } \\
\text { porous filter }\end{array}$ & Methylene blue (MB) & Halogen lamp (150 W) & $\begin{array}{l}\text { The polypropylene (PP) porous filter } \\
\text { was incorporated with reduced } \\
\text { graphene oxide (RGO) and metal oxides } \\
\text { via a simple hydrothermal approach. }\end{array}$ & $\begin{array}{l}\text { The combination of RGO and the metal } \\
\text { oxide compounds on the filters shows more } \\
\text { than } 70 \% \text { of } \mathrm{MB} \text { adsorption in } 20 \mathrm{~min} \\
\text { compared with those consisting of } \\
\text { individual materials, degradation after } \\
120 \text { min } 99 \% \text {. }\end{array}$ & [50] \\
\hline
\end{tabular}




\subsection{Photocatalytic Hybrid Materials Based on Natural Polymers}

Natural polymers derived from renewable resources or waste products can also serve as a desirable organic support for inorganic semiconductor metal oxides [77-79]. Polysaccharides, lignin, cellulose, hemicellulose, chitin, chitosan, starch or xylan, possess excellent sustainability, biodegradability and can be used as abundant industrial raw feed stock to synthesize photocatalytic hybrid materials [80-82]. Natural polymers (see structures in Figure 7) are mainly obtained by extractions from wood, plants or even residues of living organisms [83], that make them more attractive in comparison with synthetic polymers. Natural fibers are frequently used as a reinforcing composite for producing hybrid materials because they exhibit advantages, like recyclability and eco-friendliness, over their synthetic counterparts [84]. Additionally, natural fibers possess a higher volume fraction, and thus a larger loading capacity [85]. For these reasons they are widely used to produce composite materials, especially in the field of photocatalysis. For instance, depositing titanium dioxide on cellulose fiber surface allows for obtaining hybrid materials with a high degradation ratio of organic compounds like organic dye or phenolic contaminants [86] (Table 2, Entry 1). Yu et al. obtained cellulose-templated $\mathrm{TiO}_{2} / \mathrm{Ag}$ nanosponge composites with enhanced photocatalytic activities for the degradation of RhB; the synthetic procedures for this material are shown in Figure 8 [86]. The polymeric nanocomposite membranes with cellulose fibers can be also used for gas separation processes (e.g., hydrogen recovering, nitrogen generation or carbon dioxide separation) $[87,88]$. However, due to the fact that cellulose consists of monosaccharide units (Figure 7a), it is hydrophilic and exhibits a rather poor interaction with most of the non-polar compound. Many efforts have been done to obtain uniform dispersion of the fibers within the matrices. Furthermore, it is worth noting that plant fibers like cellulose possess relatively low processing temperatures $\left(<200{ }^{\circ} \mathrm{C}\right)$, and for this reason, researchers have used low-temperature techniques (e.g., sol-gel method, hydrothermal method, dip coating method, etc.) to coat natural fibers [89]. Despite this, in the open literature we can find successfully completed examples of many attempts to modify surface properties of natural fibers (see Table 2).

(a)

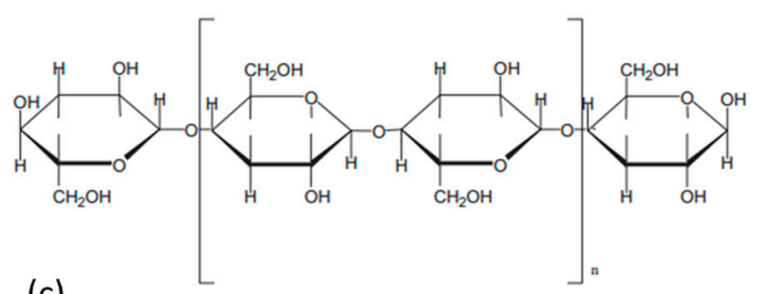

(c)

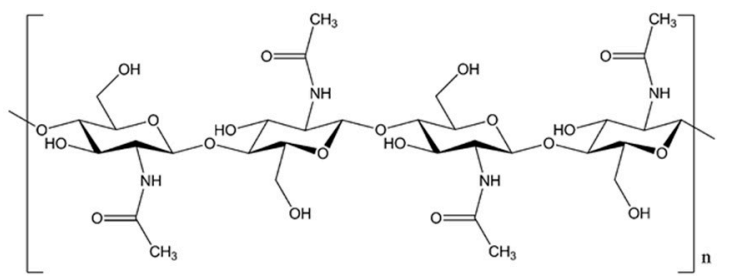

(b)

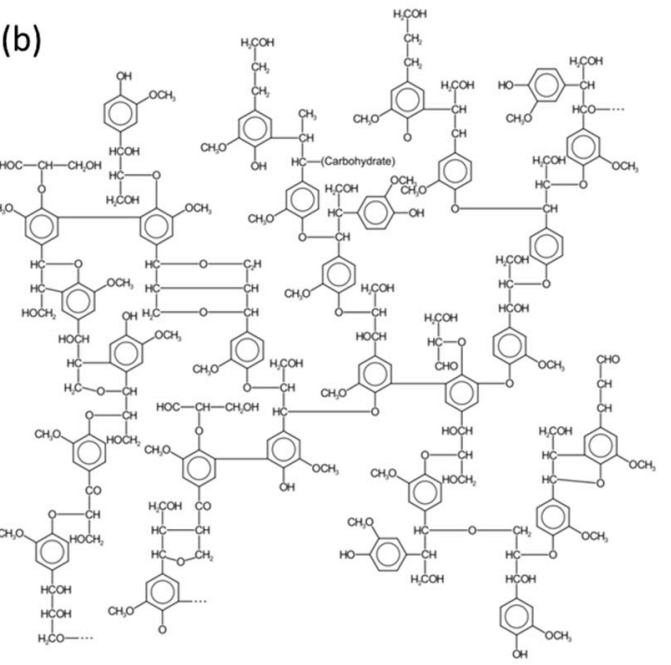

Figure 7. Structure of most common natural polymers: cellulose (a), lignin (b) and chitin (c). Reprinted from references [83] with permission from Elsevier. 


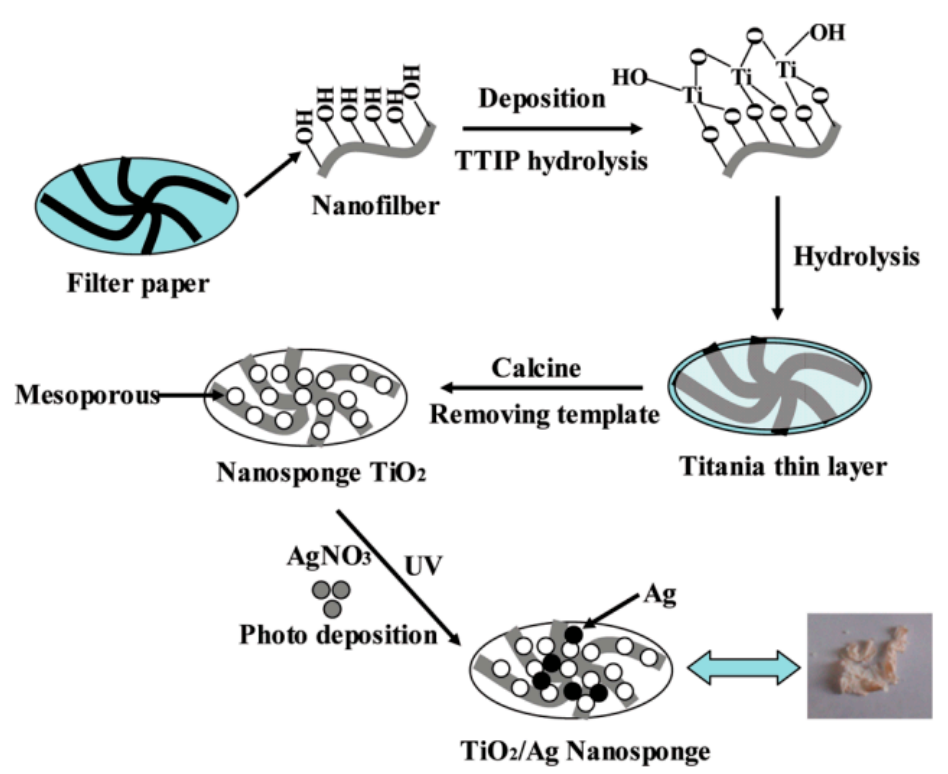

Figure 8. Schematic illustration of the synthetic approach for $\mathrm{TiO}_{2} / \mathrm{Ag}$ nanosponge materials (TTIP: titanium iso-propoxide). Reprinted with permission from [86]. Copyright (2012) American Chemical.

In contrast to hemicellulose and cellulose, lignin possesses rather a complex structure due to the different types of linkages connecting the phenylpropanoid-based units [90] (Figure 7b) and is seen as a product with little intrinsic value but potentially, for instance, can serve as a stable biopolymeric support for hybrid materials [91]. It should be noted that lignin can be used for the synthesis of functional hybrid materials with antimicrobial properties [92] as well as adsorptive properties for the removal of inorganic compounds from aqueous solutions [93]. However, the stability of biopolymers based on lignin under photocatalytic conditions is not high. Some critical review reports pointed out that photocatalytic methods can be used also to degradate lignin and lignin-based phenolic compounds [94]. From this point of view, it is interesting to study if lignin, which consists of phenylpropanoid-based structures, can be used as a support for the fabrication of stable hybrid photocatalysts with the aim of being applied for mineralization of organic contaminants in water.

Chitin (Figure 7c) represents the next most plentiful natural polysaccharide and is source of chitosan which is obtained by partial deacetylation of chitin. Due to the presence of various functional groups, chitosan can be applied as an adsorbent for the removal of different kinds of pollutants $[95,96]$. Additionally, this polymer can be used in the wide range of form, e.g., hydrogels [97], nanofiber mats [98], and nano-beads as well as powders [99]. Chitosan may have a high specific surface area as a bead or fiber, and thus exhibits strong adsorption capacities. However, all of these forms depend on the fabrication method. The formation of a highly specific surface area requires mainly specialized methods like electrospinning [100]. In the open literature, one can find the description of many other facile methods to obtain hybrid catalysts like those based on titanium dioxide [100], zinc oxide [101] (Table 2), and niobium oxide [102] among others, combined with chitosan, which can be used for water treatment processes. However, chitosan, as well as other polysaccharides have some limitations associated with wastewater treatment application, namely: they possess high swelling capacities and low resistance, especially in extreme wastewater conditions (e.g., acid medium), which may result in significant leaching. Consequently, the catalyst based on these natural polymers cannot be stable and may promote the expansion of organic matter in wastewater [103]. 
Table 2. Selected photocatalytic hybrid materials based on natural polymers used for degradation of organic contaminants.

\begin{tabular}{|c|c|c|c|c|c|c|}
\hline Entry & Polymer Hybrid Materials & Target Contaminant & Light Source & Fabrication Method & Photocatalytic Behavior & Ref. \\
\hline 1 & $\begin{array}{l}\text { Titanium dioxide }\left(\mathrm{TiO}_{2}\right) \\
\text { immobilized in cellulose matrix }\end{array}$ & Phenol & $\begin{array}{l}\text { UV }(6 \mathrm{~W}) \text { light at wavelength of } \\
254 \mathrm{~nm} \text { was used. The mean light } \\
\text { intensity equal to } 0.56 \mathrm{~mW} / \mathrm{cm}^{2} \text {. }\end{array}$ & $\begin{array}{l}\text { Composite films have been } \\
\text { prepared via a sol-gel method. }\end{array}$ & $\begin{array}{l}\text { The composite films exhibited high degradation } \\
\text { ratio ( } 90 \% \text { after } 2 \mathrm{~h} \text { of irradiation) without } \\
\text { remarkable loss of photocatalytic activity after } \\
\text { three times. }\end{array}$ & [85] \\
\hline 2 & $\begin{array}{l}\mathrm{ZnAc} / \text { cellulose acetate }(\mathrm{CA}) \\
\text { composite nanofibers }\end{array}$ & Rhodamine B and phenol & $\begin{array}{l}\text { Ultraviolet lamps (PHILIPS } 365 \mathrm{~nm} \text { ) } \\
\text { as the irradiation source. }\end{array}$ & $\begin{array}{l}\text { Electrospinning technique in } \\
\text { combination with calcination. }\end{array}$ & $\begin{array}{l}\text { Almost } 100 \% \text { of Rhodamine } \mathrm{B} \text { and } 85 \% \text { phenol } \\
\text { (after } 24 \mathrm{~h} \text { ) was decomposed in the presence of } \\
\mathrm{TiO}_{2} / \mathrm{ZnO} \text { composite nanofibers under } \\
\text { mild conditions. }\end{array}$ & {$[104]$} \\
\hline 3 & $\mathrm{ZnO} /$ cellulose hybrid nanofibers & $\begin{array}{l}\text { Methylene blue (MB) and eosin } \\
\text { yellowish (EY) dye }\end{array}$ & $\begin{array}{l}\text { Tungsten lamp ( } 500 \mathrm{~W} \text { ) was used as } \\
\text { the visible light source. }\end{array}$ & $\begin{array}{l}\text { A novel method that combines } \\
\text { electrospinning and } \\
\text { solvothermal techniques }\end{array}$ & $\begin{array}{l}\text { Nearly } 50 \% \text { of Rhodamine B was decomposed } \\
\text { after } 24 \mathrm{~h} \text { of irradiation under visible light. }\end{array}$ & {$[105]$} \\
\hline 4 & $\begin{array}{l}\text { Photoactive } \mathrm{TiO}_{2} \text { films on } \\
\text { cellulose fibers }\end{array}$ & $\begin{array}{l}\text { Methylene blue (MB) and } \\
\text { heptane-extracted bitumen fraction } \\
\text { (BF) containing a mixture of heavy } \\
\text { aromatic hydrocarbons }\end{array}$ & $\begin{array}{l}\text { Reproducible solar light } \\
\left(50 \mathrm{~mW} / \mathrm{cm}^{2}\right) .\end{array}$ & Sol-gel method & $\begin{array}{l}\text { The degradation ratio of MB reached } 90 \% \text { after } \\
20 \mathrm{~h} \text { and } 90 \% \text { for BF fraction after } 9 \mathrm{~h} \text { without } \\
\text { loss of activity after three illumination cycles. }\end{array}$ & {$[106]$} \\
\hline 5 & $\begin{array}{l}\text { Rice-straw-derived hybrid } \\
\mathrm{TiO}_{2}-\mathrm{SiO}_{2} \text { structures }\end{array}$ & Methylene blue (MB) & $\begin{array}{l}\text { UV-A }(8 \mathrm{~W}) \text { lamps }(300-450 \mathrm{~nm}) \\
\text { providing an irradiation power flux } \\
\text { of } 2.0 \mathrm{~mW} / \mathrm{cm}^{2} .\end{array}$ & Impregnation method. & $\begin{array}{l}\text { The photocatalytic decomposition of methylene } \\
\text { blue after } 90 \text { min obtained was } 100 \% \text {. }\end{array}$ & {$[107]$} \\
\hline 6 & $\begin{array}{l}\text { Chitosan (CS)-encapsulated } \mathrm{TiO}_{2} \\
\text { nanohybrid }\end{array}$ & Methylene blue (MB) & UV light at a wavelength of $365 \mathrm{~nm}$. & $\begin{array}{l}\text { Nanohybrid materials was } \\
\text { prepared by chemical } \\
\text { precipitation method. }\end{array}$ & $\begin{array}{l}\text { The catalyst showed high photocatalytic activity } \\
\text { of } 90 \% \text { degradation after } 3 \mathrm{~h} \text { of irradiation and } \\
\text { without losing photocatalytic activity after five } \\
\text { recycle tests. }\end{array}$ & {$[100]$} \\
\hline 7 & $\begin{array}{l}\mathrm{Fe}_{3} \mathrm{O}_{4} / \text { chitosan } / \mathrm{TiO}_{2} \\
\text { nanocomposites }\end{array}$ & Methylene blue (MB) & Illumination with UV light. & $\begin{array}{l}\text { Facile and low-cost method by } \\
\text { solvents thermal reduction. }\end{array}$ & $\begin{array}{l}\text { The degradation rate of methyl blue was } 93 \% \\
\text { after } 30 \text { min for } \mathrm{Fe}_{3} \mathrm{O}_{4} / \mathrm{CTS} / \mathrm{TiO}_{2} \\
\text { nanocomposites. }\end{array}$ & {$[108]$} \\
\hline
\end{tabular}




\section{Summary and Future Perspectives}

The selected studies in this short overview serve as clear examples that both natural and synthetic polymers can be successfully used in the field of hybrid innovative materials for heterogeneous photocatalysis in the context of pollutant degradation. The organic-inorganic hybrid materials exhibit significantly better photocatalytic properties than the separate components, due to the synergistic effect coming from the intrinsic properties of a photoactive semiconductor and polymers. Several key advantages can be expected from polymeric support, such as: (a) an increase of the specific surface area which consequently allows for adsorption of higher amounts of target pollutants [109-111], and (b) an improvement of the photocatalytic performance by promoting reduction of the charge carriers recombination and prolongation of the photoelectron lifetime [112]. In this mini-review, the highlighted benefits and drawbacks of natural and synthetic polymer-based photocatalytic materials will exponentially increase in importance due to the fact that accessibility of synthetic polymeric materials derived from oil, gas and carbon (non-renewable sources) will be impeded because of the decreasing amount of fossil resources. Thus, this fact turns on the alarm to look for cheap and easily available raw materials like bio-polymers that come from sources such as lignocellulosic wastes or crustacean residues to cover the increasing demand of the market for plastics. Currently, the scientific world indicates that polymer materials are the key promising components of the next generation of photocatalytic hybrid materials for water and air treatment processes [113,114]. However, there are still some limitations on this topic (Table 3) that should be studied extensively.

Table 3. The main pros/cons of using synthetic polymers and biopolymers for photocatalytic hybrid materials.

\begin{tabular}{ccc}
\hline & Synthetic Polymers & Biopolymers \\
\hline Availability & Decreasing & High \\
Physicochemical resistance & High & Low \\
Thermal stability & High & Low \\
Large-scale applications & Possible & Difficult \\
Environmental-friendly & No & Yes \\
Cost of production & Low & High \\
Sustainability & Low & High \\
\hline
\end{tabular}

Acknowledgments: Juan C. Colmenares is very grateful for the partial support from the National Science Centre in Poland within Sonata Bis Project No. 2015/18/E/ST5/00306.

Author Contributions: The authors contributed equally to this work.

Conflicts of Interest: The authors declare no conflict of interest. The founding sponsors had no role in the design of the study; in the collection, analyses, or interpretation of data; in the writing of the manuscript, and in the decision to publish the results.

\section{References}

1. Pichat, P.; Oills, D. Photocatalytic Treatment of Water: Irradiance Influences. In Photocatalysis and Water Purification: From Fundamentals to Recent Applications, 1st ed.; Pichat, P., Ed.; Wiley-VCH Verlag GmbH \& Co., KGaA: Weinheim, Germany, 2013; pp. 311-333.

2. George, C.; Beeldens, A.; Barmpas, F.; Doussin, J.F.; Manganelli, G.; Herrmann, H.; Kleffmann, J.; Mellouki, A. Impact of photocatalytic remediation of pollutants on urban air quality. Front. Environ. Sci. Eng. 2016, 10. [CrossRef]

3. Yu, C.; Zhou, W.; Yu, J.C.; Liu, H.; Wei, L. Design and fabrication of heterojunction photocatalysts for energy conversion and pollutant degradation. Chin. J. Catal. 2014, 35, 1609-1618. [CrossRef]

4. Peng, Y.; Shang, L.; Bian, T.; Zhao, Y.; Zhou, C.; Yu, H.; Tunga, C.; Zhang, T. Flower-like CdSe ultrathin nanosheet assemblies for enhanced visible-light-driven photocatalytic $\mathrm{H}_{2}$ production. Chem. Commun. 2015, 51, 4677-4680. [CrossRef] [PubMed] 
5. Corrigan, N.; Shanmugam, S.; Xu, J.; Boyer, C. Photocatalysis in organic and polymer synthesis. Chem. Soc. Rev. 2016, 45, 6165-6212. [CrossRef] [PubMed]

6. Penga, Y.; Shanga, L.; Cao, Y.; Wang, Q.; Zhao, Y.; Zhou, C.; Bian, T.; Wu, L.Z.; Tung, C.H.; Zhang, T. Effects

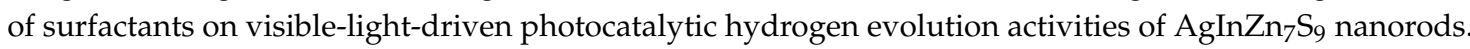
Appl. Surf. Sci. 2015, 358, 485-490. [CrossRef]

7. Zhao, Y.; Chen, G.; Bian, T.; Zhou, C.; Waterhouse, G.I.N.; Wu, L.Z.; Tung, C.H.; Smith, L.J.; O'Hare, D.; Zhang, T. Defect-Rich Ultrathin ZnAl-Layered Double Hydroxide Nanosheets for Efficient Photoreduction of $\mathrm{CO}_{2}$ to $\mathrm{CO}$ with Water. Adv. Mater. 2015, 27, 7823-7831. [CrossRef]

8. Yu, H.; Shi, R.; Zhao, Y.; Bian, T.; Zhao, Y.; Zhou, C.; Waterhouse, G.I.N.; Wu, L.Z.; Tung, C.H.; Zhang, T. Alkali-Assisted Synthesis of Nitrogen Deficient Graphitic Carbon Nitride with Tunable Band Structures for Efficient Visible-Light-Driven Hydrogen Evolution. Adv. Mater. 2017, 29, 1605148. [CrossRef] [PubMed]

9. Colmenares, J.C.; Varma, R.S.; Lisowski, P. Sustainable hybrid photocatalysts: Titania immobilized on carbon materials derived from renewable and biodegradable resources. Green Chem. 2016, 18, 5736-5750. [CrossRef]

10. Colmenares, J.C.; Kuna, E.; Lisowski, P. Synthesis of Photoactive Materials by Sonication: Application in Photocatalysis and Solar Cells. Top. Curr. Chem. 2016, 374. [CrossRef] [PubMed]

11. Colmenares, J.C.; Xu, Y.J. Heterogeneous Photocatalysis: From Fundamentals to Green Applications. In Heterogeneous Photocatalysis, 1st ed.; He, L.N., Rogers, R.D., Su, D., Tundo, P., Zhang, C., Eds.; Springer: Berlin/Heidelberg, Germany, 2016. [CrossRef]

12. Arora, A.K.; Jaswal, V.S.; Singh, K.; Singh, R. Applications of Metal/Mixed Metal Oxides as Photocatalyst: (A Review). Orient. J. Chem. 2016, 32, 2035-2042. [CrossRef]

13. Zhao, Y.; Jia, X.; Waterhouse, G.I.N.; Wu, L.Z.; Tung, C.H.; O’Hare, D.; Zhang, T. Layered Double Hydroxide Nanostructured Photocatalysts for Renewable Energy Production. Adv. Energy Mater. 2016, 6. [CrossRef]

14. Zhang, Z.; Zheng, T.; Li, X.; Xu, J.; Zeng, H. Progress of Carbon Quantum Dots in Photocatalysis Applications. Part. Part. Syst. Charact. 2016, 33, 447-588. [CrossRef]

15. Wang, W.; Tadéa, M.O.; Shao, Z. Research progress of perovskite materials in photocatalysis- and photovoltaics-related energy conversion and environmental treatment. Chem. Soc. Rev. 2015, 44, 5371-5408. [CrossRef] [PubMed]

16. Khan, M.M.; Adil, S.F.; Al-Mayouf, A. Metal oxides as photocatalysts. J. Saudi Chem. Soc. 2015, 19, $462-464$. [CrossRef]

17. Ahmad, R.; Ahmad, Z.; Khan, A.U.; Mastoi, N.R.; Aslam, M.; Kim, J. Photocatalytic systems as an advanced environmental remediation: Recent developments, limitations and new avenues for applications. J. Environ. Chem. Eng. 2016, 4, 4143-4164. [CrossRef]

18. Schneider, J.; Bahnemann, D.; Ye, J.; Puma, G.L.; Dionysiou, D.D. Photocatalysis, Vol. 1: Fundamentals and Perspectives; Vol. 2: Applications, 1st ed.; RSC Publishing: Cambridge, UK, 2016; pp. 1-936.

19. Pichat, P. Photocatalysis: Fundamentals, Materials and Potential, 1st ed.; MDPI: Basel, Switzerland, 2016; pp. 3-650.

20. Nosaka, Y.; Nosaka, A. Introduction to Photocatalysis: From Basic Science to Applications, 1st ed.; RSC Publishing: Cambridge, UK, 2016; pp. 1-272.

21. Portela, R.; Hernández-Alonso, M.D. Design of Advanced Photocatalytic Materials for Energy and Environmental Applications, 1st ed.; Coronado, J., Fresno, F., Hernández-Alonso, M.D., Portela, R., Eds.; Springer: London, UK, 2013; pp. 35-36.

22. Chaturvedi, S.; Dave, P.N. Environmental Application of Photocatalysis. Mater. Sci. Forum 2012, 734, $273-294$. [CrossRef]

23. Jiang, L.; Wang, Y.; Feng, C. Application of Photocatalytic Technology in Environmental Safety. Procedia Eng. 2012, 45, 993-997. [CrossRef]

24. Nakataa, K.; Fujishimaa, A. $\mathrm{TiO}_{2}$ photocatalysis: Design and applications. J. Photochem. Photobiol. C Photochem. Rev. 2012, 13, 169-189. [CrossRef]

25. Sanchez, C.; Ribot, F.; Lebeau, B. Molecular design of hybrid organic-inorganic nanocomposites synthesized via sol-gel chemistry. J. Mater. Chem. 1999, 9, 35-44. [CrossRef]

26. Singh, S.; Mahalingam, H.; Singh, P.K. Polymer-supported titanium dioxide photocatalysts for environmental remediation: A review. Appl. Catal. A 2013, 462-463, 178-195. [CrossRef]

27. Vilatela, J.J.; Eder, D. Nanocarbon composites and hybrids in sustainability: A review. ChemSusChem 2012, 12, 456-478. [CrossRef] [PubMed] 
28. Thakur, R.S.; Chaudhary, R.; Singh, C. Fundamentals and applications of the photocatalytic treatment for the removal of industrial organic pollutants and effects of operational parameters: A review. J. Renew. Sustain. Energy Rev. 2010, 2, 042701. [CrossRef]

29. Peng, Y.; Shang, L.; Cao, Y.; Waterhouse, G.I.N.; Zhou, C.; Bian, T.; Wu, L.Z.; Tunga, C.H.; Zhang, T. Copper(I) cysteine complexes: Efficient earth-abundant oxidation co-catalysts for visible light-driven photocatalytic $\mathrm{H}_{2}$ production. Chem. Commun. 2015, 51, 12556-12599. [CrossRef] [PubMed]

30. Reddy, K.R.; Hassan, M.; Gomes, V.G. Hybrid nanostructures based on titanium dioxide for enhanced photocatalysis. Appl. Catal. A Gen. 2015, 489, 1-16. [CrossRef]

31. Gaya, U.I.; Abdullah, A.H. Heterogeneous photocatalytic degradation of organic contaminants over titanium dioxide: A review of fundamentals, progress and problems. J. Photochem. Photobiol. C Photochem. Rev. 2008, 9, 1-12. [CrossRef]

32. Ghosh, T.; Oh, W.C. Carbon Based Titania Photocatalysts. Asian J. Chem. 2012, 24, 5419-5423.

33. Muggeridge, A.; Cockin, A.; Webb, K.; Frampton, H.; Collins, I.; Moulds, T.; Salino, P. Recovery rates, enhanced oil recovery and technological limits. Philos. Trans. R. Soc. A 2013, 372, 20120320. [CrossRef] [PubMed]

34. How Much Oil Is Used to Make Plastic? Available online: http://www.eia.gov/tools/faqs/faq.cfm?id=34\& $\mathrm{t}=6$ (accessed on 25 April 2016).

35. Gervet, B. The Use of Crude Oil in Plastic Making Contributes to Global Warming; Department of Civil and Environmental Engineering Luleå University of Technology: Luleå, Sweden, May 2007.

36. Compendium of Polymer Terminology and Nomenclature. Available online: https://www.iupac.org/ cms/wp-content/uploads/2016/01/Compendium-of-Polymer-Terminology-and-Nomenclature-IUPACRecommendations-2008.pdf (accessed on 19 January 2009).

37. Olatunji, O. Classification of Natural Polymers; Springer: Basel, Switzerland, 2015; pp. 1-17.

38. Luckachan, G.E.; Pillai, C.K.S. Biodegradable Polymers-A Review on Recent Trends and Emerging Perspectives. J. Polym. Environ. 2011, 19, 637-676. [CrossRef]

39. Jiang, L.; Zhang, J. Biodegradable and Biobased Polymers. In Handbook of Biopolymers and Biodegradable Plastics: Properties, Processing and Applications, 1st ed.; Ebnesajjad, S., Andrew, W., Eds.; Elsevier: Oxford, UK, 2013; pp. 109-124.

40. Sionkowska, A. Current research on the blends of natural and synthetic polymers as new biomaterials: Review. Prog. Polym. Sci. 2011, 36, 1254-1276. [CrossRef]

41. Gupta, A.P.; Kumar, V. New emerging trends in synthetic biodegradable polymers-Polylactide: A critique. Eur. Polym. J. 2007, 43, 4053-4074. [CrossRef]

42. Yu, Z.; Mielczarski, E.; Mielczarski, J.; Laub, C.; Buffat, P.; Klehm, U.; Albers, P.; Lee, K.; Kulike, A.; Kiwi-Minerska, L.; et al. Preparation, stabilization and characterization of $\mathrm{TiO}_{2}$ on thin polyethylene films (LDPE). Photocatalytic applications. Water Res. 2007, 41, 862-874.

43. Ma, S.; Meng, J.; Li, J.; Zhang, Y.; Ni, L. Synthesis of catalytic polypropylene membranes enabling visible-light-driven photocatalytic degradation of dyes in water. J. Membr. Sci. 2014, 453, 221-229. [CrossRef]

44. Zan, L.; Tian, L.; Liu, Z.; Peng, Z. A new polystyrene- $-\mathrm{TiO}_{2}$ nanocomposite film and its photocatalytic degradation. Appl. Catal. A Gen. 2004, 264, 237-242.

45. Taylor, D.M.; Lewis, T.J. Electrical conduction in polyethylene terephthalate and polyethylene films. J. Phys. D Appl. Phys. 1971, 4, 1346-1354. [CrossRef]

46. Wang, D.; Shi, L.; Luo, Q.; Li, X.; An, J. An efficient visible light photocatalyst prepared from $\mathrm{TiO}_{2}$ and polyvinyl chloride. J. Mater. Sci. 2012, 47, 2136-2145. [CrossRef]

47. Araújo, V.D.; Tranquilin, R.L.; Motta, F.V.; Paskocimas, C.A.; Bernardi, M.I.B.; Cavalcante, L.S.; Andres, J.; Longo, E.; Bomio, M.R.D. Effect of polyvinyl alcohol on the shape, photoluminescence and photocatalytic properties of $\mathrm{PbMoO}_{4}$ microcrystals. Mater. Sci. Semicond. Process. 2014, 26, 425-430. [CrossRef]

48. Fateh, R.; Dillert, R.; Bahnemann, D. Preparation and characterization of transparent hydrophilic photocatalytic $\mathrm{TiO}_{2} / \mathrm{SiO}_{2}$ thin films on polycarbonate. Langmuir 2015, 29, 3730-3739. [CrossRef] [PubMed]

49. Tennakone, K.; Tilakaratne, C.T.K.; Kottegoda, I.R.M. Photocatalytic degradation of organic contaminants in water with $\mathrm{TiO}_{2}$ supported on polyethene films. J. Photochem. Photobiol. A Chem. 1995, 87, 177-179. [CrossRef]

50. Ariffin, S.N.; Lima, H.N.; Jumeri, F.A.; Zobir, M.; Abdullah, A.H.; Ahmad, M.; Ibrahim, N.A.; Huang, N.M.; Teo, P.S.; Muthoosamy, K.; et al. Modification of polypropylene filter with metal oxide and reduced graphene oxide for water treatment. Ceram. Int. 2014, 40, 6927-6936. [CrossRef] 
51. Li, M.; Li, G.; Fan, Y.; Jiang, J.; Ding, Q.; Dai, X.; Mai, K. Effect of nano-ZnO-supported 13X zeolite on photo-oxidation degradation and antimicrobial properties of polypropylene random copolymer. Polym. Bull. 2014, 71, 2981-2997. [CrossRef]

52. Colmenares, J.C.; Kuna, E.; Jakubiak, S.; Michalski, J.; Kurzydłowski, K. Polypropylene nonwoven filter with nanosized ZnO rods: Promising hybrid photocatalyst for water purification. Appl. Catal. B Environ. 2015, 170-171, 273-282. [CrossRef]

53. Sakthivel, S.; Neppolian, B.; Shankar, M.V.; Arabindoo, B.; Palanichamy, M.; Murugesan, V. Solar photocatalytic degradation of azo dye: Comparison of photocatalytic efficiency of $\mathrm{ZnO}_{\text {and }} \mathrm{TiO}_{2}$. Sol. Energy Mater. Sol. Cells 2003, 77, 65-82. [CrossRef]

54. Preparation and Characterization of Composite PES/Nanoparticle Membranes. Available online: https:/ /web.wpi.edu/Pubs/E-project/Available/E-project-042313--223351/unrestricted/Sheppard_ MQP_Report.pdf (accessed on 25 April 2013).

55. Gong, B.; Peng, Q.; Na, J.S.; Parsons, G.N. Highly active photocatalytic ZnO nanocrystalline rods supported on polymer fiber mats: Synthesis using atomic layer deposition and hydrothermal crystal growth. Appl. Catal. A Gen. 2011, 407, 211-216. [CrossRef]

56. Hong, J.; He, Y. Polyvinylidene fluoride ultrafiltration membrane blended with nano-ZnO particle for photo-catalysis self-cleaning. Desalination 2014, 332, 67-75. [CrossRef]

57. Moafi, H.F.; Shojaie, A.F.; Zanjanchi, M.A. Semiconductor-assisted self-cleaning polymeric fibers based on zinc oxide nanoparticles. J. Appl. Polym. Sci. 2011, 121, 3641-3650. [CrossRef]

58. Sun, L.; Shi, Y.; Li, B.; Li, X.; Wang, Y. Preparation and characterization of polypyrrole $/ \mathrm{TiO}_{2}$ nanocomposites by reverse microemulsion polymerization and its photocatalytic activity for the degradation of methyl orange under natural light. Polym. Compos. 2013, 34, 1076-1080. [CrossRef]

59. Ansari, M.O.; Khan, M.M.; Ansari, S.A.; Cho, M.H. Polythiophene nanocomposites for photodegradation applications: Past, present and future. J. Saudi Chem. Soc. 2015, 19, 494-504. [CrossRef]

60. Aizawa, M.; Watanabe, S.; Shinohara, H.; Shirakawa, H. Photodoping of polyacetylene films. J. Chem. Soc. Chem. Commun. 1985, 2, 62-63. [CrossRef]

61. Yang, M.; Dan, Y. Preparation of poly(methyl methacrylate)/titanium oxide composite particles via in-situ emulsion polymerization. J. Appl. Polym. Sci. 2006, 101, 4056-4063. [CrossRef]

62. Zhang, Z.; Zheng, T.; Xu, J.; Zeng, H. Polythiophene/ $\mathrm{Bi}_{2} \mathrm{MoO}_{6}$ : A novel conjugated polymer/nanocrystal hybrid composite for photocatalysis. J. Mater. Sci. 2016, 51, 3846-3853. [CrossRef]

63. Wang, X.; Maeda, K.; Thomas, A.; Takanabe, K.; Xin, G.; Carlsson, J.M.; Domen, K.; Antonietti, M. A metal-free polymeric photocatalyst for hydrogen production from water under visible light. Nat. Mater. 2009, 8, 76-80. [CrossRef] [PubMed]

64. Ghosh, S.; Kouame, N.A.; Remita, S.; Ramos, L.; Goubard, F.; Aubert, P.H.; Dazzi, A.; Deniset-Besseau, A.; Remita, H. Visible-light active conducting polymer nanostructures with superior photocatalytic activity. Sci. Rep. 2015, 5. [CrossRef] [PubMed]

65. Ullah, H.; Tahir, A.A.; Mallick, T.K. Polypyrrole/ $\mathrm{TiO}_{2}$ composites for the application of photocatalysis. Sens. Actuators B Chem. 2017, 241, 1161-1169. [CrossRef]

66. Magalhães, F.; Mourab, F.C.C.; Lago, R.M. $\mathrm{TiO}_{2}$ /LDPE composites: A new floating photocatalyst for solar degradation of organic contaminants. Desalination 2011, 276, 266-271. [CrossRef]

67. Naskar, S.; Pillay, A.S.; Chanda, M. Photocatalytic degradation of organic dyes in aqueous solution with $\mathrm{TiO}_{2}$ nanoparticles immobilized on foamed polyethylene sheet. J. Photochem. Photobiol. A Chem. 1998, 3, 257-264. [CrossRef]

68. Jin, L.; Wu, H.; Morbidelli, M. Synthesis of Water-Based Dispersions of Polymer $/ \mathrm{TiO}_{2} \mathrm{Hybrid}_{\text {Nanospheres. }}$ Nanomaterials 2015, 5, 1454-1468. [CrossRef] [PubMed]

69. Nabid, M.R.; Golbabaee, M.; Moghaddam, A.B.; Dinarvand, R.; Sedghi, R. Polyaniline/ $\mathrm{TiO}_{2}$ Nanocomposite: Enzymatic Synthesis and Electrochemical Properties. Int. J. Electrochem. Sci. 2008, 3, 1117-1126.

70. Wang, X.; Wang, X.; Wang, W.; Zhao, J. Enhanced visible light photocatalytic activity of a floating photocatalyst based on B-N-codoped $\mathrm{TiO}_{2}$ grafted on expanded perlite. RSC Adv. 2015, 5, 41385-41392. [CrossRef]

71. Kan, W.Q.; Liu, B.; Yang, J.; Liu, Y.Y.; Ma, J.F. A Series of Highly Connected Metal-Organic Frameworks Based on Triangular Ligands and d10 Metals: Syntheses, Structures, Photoluminescence, and Photocatalysis. Cryst. Growth Des. 2012, 12, 2288-2298. [CrossRef] 
72. Wang, C.; Xie, Z.; deKrafft, K.E.; Lin, W. Light-Harvesting Cross-Linked Polymers for Efficient Heterogeneous Photocatalysis. ACS Appl. Mater. Interfaces 2012, 4, 2288-2294. [CrossRef] [PubMed]

73. Meyer, K.; Ranocchiari, M.; Bokhoven, J.A. Metal organic frameworks for photo-catalytic water splitting. Energy Environ. Sci. 2015, 8, 1923-1937. [CrossRef]

74. Li, C.; Chen, R.; Zhang, X.; Shu, S.; Xiong, J.; Zheng, Y.; Dong, W. Electrospinning of $\mathrm{CeO}_{2}-\mathrm{ZnO}$ composite nanofibers and their photocatalytic property. Mater. Lett. 2011, 65, 1327-1330. [CrossRef]

75. Baruah, S.; Thanachayanont, C.; Dutta, J. Growth of ZnO nanowires on nonwoven polyethylene fibers. Sci. Technol. Adv. Mater. 2008, 9, 025009. [CrossRef] [PubMed]

76. Zhang, Z.; Shao, C.; Li, X.; Zhang, L.; Xue, H.; Wang, C.; Liu, Y. Electrospun Nanofibers of $\mathrm{ZnO}^{-} \mathrm{SnO}_{2}$ Heterojunction with High Photocatalytic Activity. J. Phys. Chem. C 2010, 114, 7920-7925. [CrossRef]

77. Gao, M.; Peh, C.K.G.; Onga, W.L.; Ho, G.W. Green chemistry synthesis of a nanocomposite graphene hydrogel with three-dimensional nano-mesopores for photocatalytic $\mathrm{H}_{2}$ production. RSC Adv. 2013, 3, 13169-13177. [CrossRef]

78. Petzold, J.C.; Herrington, T.M. The measurement of concentration and stability of weak acids and a study of the ionisation of polysaccharides using buffer capacity curves. Macromol. Chem. Phys. 2003, 192, 1741-1748. [CrossRef]

79. Zhang, G.; Shen, X.; Yang, Y. Facile Synthesis of Monodisperse Porous ZnO Spheres by a Soluble Starch-Assisted Method and Their Photocatalytic Activity. J. Phys. Chem. C 2011, 115, 7145-7152. [CrossRef]

80. Hamdi, A.; Boufi, S.; Bouattour, S. Phthalocyanine/chitosan- $\mathrm{TiO}_{2}$ photocatalysts: Characterization and photocatalytic activity. Appl. Surf. Sci. 2015, 339, 128-136. [CrossRef]

81. Benabid, F.Z.; Zouai, F. Natural polymers: Cellulose, chitin, chitosan, gelatin, starch, carrageenan, xylan and dextran. Alger. J. Nat. Prod. 2016, 4, 348-357.

82. Fu, S.; Song, P.; Liu, X. Thermal and flame retardancy properties of thermoplastics/natural fiber biocomposites. In Advanced High Strength Natural Fibre Composites in Construction, 1st ed.; Gwen, J., Ed.; Wood Publishing: Duxford, UK, 2017; pp. 479-508. [CrossRef]

83. Thakura, V.K.; Thakurb, M.K. Processing and characterization of natural cellulose fibers/thermoset polymer composites. Carbohydr. Polym. 2014, 109, 102-117. [CrossRef] [PubMed]

84. Li, H.; Fu, S.; Peng, L. Surface modification of cellulose fibers by layer-by-layer self-assembly of lignosulfonates and $\mathrm{TiO}_{2}$ nanoparticles: Effect on photocatalytic abilities and paper properties. Fibers Polym. 2013, 14, 1794-1802. [CrossRef]

85. Zeng, J.; Liu, S.; Cai, J.; Zhang, L. TiO 2 Immobilized in Cellulose Matrix for Photocatalytic Degradation of Phenol under Weak UV Light Irradiation. J. Phys. Chem. C 2010, 114, 7806-7811. [CrossRef]

86. Yu, D.H.; Yu, X.; Wang, C.; Liu, X.C.; Xing, Y. Synthesis of Natural Cellulose-Templated $\mathrm{TiO}_{2} / \mathrm{Ag}$ Nanosponge Composites and Photocatalytic Properties. ACS Appl. Mater. Interfaces 2012, 4, 2781-2788. [CrossRef] [PubMed]

87. Ahmadizadegan, $\mathrm{H}$. Surface modification of $\mathrm{TiO}_{2}$ nanoparticles with biodegradable nanocellolose and synthesis of novel polyimide/cellulose/ $\mathrm{TiO}_{2}$ membrane. J. Colloid Interface Sci. 2017, 491, 390-400. [CrossRef] [PubMed]

88. Foruzanmehr, M.R.; Vuillaume, P.Y.; Robert, M.; Elkoun, S. The effect of grafting a nano- $\mathrm{TiO}_{2}$ thin film on physical and mechanical properties of cellulosic natural fibers. Mater. Des. 2015, 85, 671-678. [CrossRef]

89. Horvath, A.L. Solubility of structurally complicated materials: I. wood. J. Phys. Chem. 2006, 35, 77-92. [CrossRef]

90. Ten, E.; Vermerris, W. Functionalized Polymers from Lignocellulosic Biomass: State of the Art. Polymers 2013, 5, 600-642. [CrossRef]

91. Dong, Y.Y.; Li, S.M.; Ma, M.G.; Zhao, J.J.; Sun, R.C.; Wang, S.P. Environmentally-friendly sonochemistry synthesis of hybrids from lignocelluloses and silver. Carbohydr. Polym. 2014, 102, 445-452. [CrossRef] [PubMed]

92. Klapiszewski, Ł.; Siwińska-Stefańska, K.; Kołodyńska, D. Preparation and characterization of novel $\mathrm{TiO}_{2}$ /lignin and $\mathrm{TiO}_{2}-\mathrm{SiO}_{2}$ /lignin hybrids and their use as functional biosorbents for $\mathrm{Pb}(\mathrm{II})$. Chem. Eng. J. 2017, 314, 169-181. [CrossRef]

93. Kansala, S.K.; Singh, M.; Sud, D. Studies on $\mathrm{TiO}_{2} / \mathrm{ZnO}$ photocatalysed degradation of lignin. J. Hazard. Mater. 2008, 153, 412-417. [CrossRef] [PubMed]

94. Pandey, K.K. A note on the influence of extractives on the photo-discoloration and photo-degradation of wood. Polym. Degrad. Stab. 2005, 87, 375-379. [CrossRef]

95. Chen, X.; Chew, S.L.; Kerton, F.M.; Yan, N. Direct conversion of chitin into a N-containing furan derivative. Green Chem. 2014, 16, 2204-2212. [CrossRef] 
96. Tang, H.; Zhou, W.; Zhang, L. Adsorption isotherms and kinetics studies of malachite green on chitin hydrogels. J. Hazard. Mater. 2012, 209-210, 218-225. [CrossRef] [PubMed]

97. Naseri, N.; Kristiina, O.; Aji, P.M. Electrospun Chitosan Nanofiber Random Mats Reinforced with Chitin and Cellulose Nanocrystals for Wound Dressing Application. 2016. Available online: http:/ /www.diva-portal. org/smash/record.jsf?pid=diva2\%3A1011676\&dswid=-5388 (accessed on 11 May 2017).

98. Muzzarelli, R.A. Biomedical exploitation of chitin and chitosan via mechano-chemical disassembly, electrospinning, dissolution in imidazolium ionic liquids, and supercritical drying. Mar. Drugs 2010, 9, 1510-1533. [CrossRef] [PubMed]

99. Kamal, T.; Anwar, Y.; Khan, S.B.; Tariq Saeed Chania, M.; Asiria, A.B. Dye adsorption and bactericidal properties of $\mathrm{TiO}_{2}$ /chitosan coating layer. Carbohydr. Polym. 2016, 148, 153-160. [CrossRef] [PubMed]

100. Haldorai, Y.; Shim, J.J. Novel chitosan- $-\mathrm{TiO}_{2}$ nanohybrid: Preparation, characterization, antibacterial, and photocatalytic properties. Polym. Compos. 2014, 35, 327-333. [CrossRef]

101. Salehi, R.; Arami, M.; Mahmoodi, N.M.; Bahrami, H.; Khorramfar, S. Novel biocompatible composite (Chitosan-zinc oxide nanoparticle): Preparation, characterization and dye adsorption properties. Colloids Surf. B Biointerfaces 2010, 80, 86-93. [CrossRef] [PubMed]

102. Torres, J.D.; Faria, E.A.; De Souza, J.R.; Prado, A.G.S. Preparation of photoactive chitosan-niobium (V) oxide composites for dye degradation. J. Photochem. Photobiol. A Chem. 2006, 182, 202-206. [CrossRef]

103. Sabar, S.; Nawi, M.A.; Ngah, W.S.W. Photocatalytic removal of Reactive Red 4 dye by immobilised layer-by-layer $\mathrm{TiO}_{2}$ /cross-linked chitosan derivatives system. Desalin. Water Treat. 2014, 57, 5851-5857. [CrossRef]

104. Liu, H.; Yang, J.; Liang, J.; Huang, J.; Tang, C. ZnO Nanofiber and Nanoparticle Synthesized through Electrospinning and Their Photocatalytic Activity under Visible Light. J. Am. Chem. Soc. 2008, 91, 1287-1291. [CrossRef]

105. Ye, S.; Zhang, D.; Liu, J.; Zhou, J. ZnO Nanocrystallites/Cellulose Hybrid Nanofibers Fabricated by Electrospinning and Solvothermal Techniques and Their Photocatalytic Activity. J. Appl. Polym. Sci. 2011, 121, 1757-1764. [CrossRef]

106. Uddin, M.J.; Cesano, F.; Bonino, F.; Bordiga, S.; Spoto, G.; Scarano, D.; Zecchina, A. Photoactive $\mathrm{TiO}_{2}$ films on cellulose fibres: Synthesis and characterization. J. Photochem. Photobiol. A Chem. 2007, 189, 286-294. [CrossRef]

107. Ge, Y.; Xiang, Y.; He, Y.; Ji, M.; Song, G. Preparation of $\mathrm{Zn}-\mathrm{TiO}_{2} / \mathrm{RH} / \mathrm{Fe}_{3} \mathrm{O}_{4}$ composite material and its photocatalytic degradation for the dyes in wastewater. Desalin. Water Treat. 2016, 57, 9837-9844. [CrossRef]

108. Choia, C.; Hwanga, K.J.; Kimb, Y.J.; Kimb, G.; Parkc, J.Y.; Sungho, J. Rice-straw-derived hybrid TiO2-SiO2 structures with enhanced photocatalytic properties for removal of hazardous dye in aqueous solutions. Nano Energy 2016, 20, 76-83. [CrossRef]

109. Lee, M.; Chen, B.Y.; Walter Den, W. Chitosan as a Natural Polymer for heterogeneous Catalysts Support: A Short Review on Its Applications. Appl. Sci. 2015, 5, 1272-1283. [CrossRef]

110. Luo, L.; Yang, L.C.; Xiao, M.; Bian, L.; Yuan, B.; Liu, Y.; Jiang, F.; Pan, X. A novel biotemplated synthesis of $\mathrm{TiO}_{2} /$ wood charcoal composites for synergistic removal of bisphenol A by adsorption and photocatalytic degradation. Chem. Eng. J. 2015, 262, 1275-1283. [CrossRef]

111. Ohtani, N.; Tonoi, M. Improved Photoluminescence Lifetime of Organic Emissive Materials Embedded in Organic-Inorganic Hybrid Thin Films Fabricated by Sol-Gel Method Using Tetraethoxysilane. Mol. Cryst. Liq. Cryst. 2014, 599, 132-138. [CrossRef]

112. Yan, S.C.; Lv, S.B.; Li, Z.S.; Zouabd, Z.G. Organic-inorganic composite photocatalyst of g-C( $\left.\left.{ }_{3}\right) \mathrm{N}_{4}\right)$ and $\mathrm{TaON}$ with improved visible light photocatalytic activities. Dalton Trans. 2010, 39, 1488-1491. [CrossRef] [PubMed]

113. Corma, A.; Navarro, M.T.; Rey, F.; Ruiz, V.R.; Sabater, M.J. Direct synthesis of a photoactive inorganic-organic mesostructured hybrid material and its application as a photocatalyst. ChemPhysChem 2010, 10, 1084-1089. [CrossRef] [PubMed]

114. Foruzanmehr, M.R.; Vuillaum, P.Y.; Elkoun, S.; Robert, M. Physical and mechanical properties of PLA composites reinforced by $\mathrm{TiO}_{2}$ grafted flax fibers. Mater. Des. 2016, 106, 295-304. [CrossRef]

(C) 2017 by the authors. Licensee MDPI, Basel, Switzerland. This article is an open access article distributed under the terms and conditions of the Creative Commons Attribution (CC BY) license (http:/ / creativecommons.org/licenses/by/4.0/). 